\title{
ETHNOCULTURAL COMPETENCIES OF A TEACHER IN THE CONTEXT OF EDUCATION DIGITALIZATION
}

\author{
COMPETÊNCIAS ETNOCULTURAIS DE UM PROFESSOR NO CONTEXTO DA \\ DIGITALIZAÇÃO DA EDUCAÇÃO
}

\author{
COMPETENCIAS ETNOCULTURALES DE UN PROFESOR EN EL CONTEXTO DE \\ LA DIGITALIZACIÓN DE LA EDUCACIÓN
}

\author{
Irina V. TERENTYEVA ${ }^{1}$ \\ Anastasia V. FAKHRUTDINOVA ${ }^{2}$ \\ Svetlana N. FEDOROVA ${ }^{3}$ \\ Igor V. GAIDAMASHKO ${ }^{4}$ \\ Guzaliya Z. FAHRUTDINOVA
}

\begin{abstract}
The topicality of this research problem is based on the necessity to create a digital educational environment and expand prospects of online education that is realized in correspondence with the project "Modern digital educational environment", approved by the Government of the Russian Federation, within the framework of implementing the state-run program "Education development" in 2013-2020. In the context of education digitalization, the requirements for teachers' ethnocultural competencies also change and acquire new content. Consequently, the aim of the research is to elaborate and analyze the content of ethnocultural competencies in the context of education digitalization, as well as to reveal and experimentally verify the effectiveness of practical experience of an educational institution in forming future teachers' ethnocultural competencies. This article discusses the experience of the Faculty of Psychology and Pedagogy of Mari State University in this direction. Research methods: theoretical methods, as far as empirical methods are concerned, a questionnaire and a pedagogical experiment were used. The 50 participants of this experiment are fourth and fifth-year students pursuing a bachelor's degree in Psychology and Pedagogy. The research results conclude that it is necessary to implement system-based and civilizational approaches when forming ethnocultural competencies of future teachers in the context of education digitalization. In this case, it will be possible to form a person adequate to the digital economy and able to use digital technologies in their ethnically oriented work. These research results can be applied to design curriculums and academic course syllabuses of higher education, as
\end{abstract}

\footnotetext{
${ }^{1}$ Kazan Federal University (KPFU), Kazan - Russia. Professor of the Department of International Relations, World Politics and Diplomacy Institute of International Relations. Doctor of Sciences (Pedagogics). ORCID: https://orcid.org/0000-0002-7072-6822.E-mail: iterenteva49@mail.ru

${ }^{2}$ Kazan Federal University (KPFU), Kazan - Russia. Professor of the Department of foreign languages, Institute of International Relations. ORCID: https://orcid.org/0000-0001-7872-7507. E-mail: avfach@mail.ru

${ }^{3}$ Mari state University (MARSU), Yoshkar-Ola - Russia. Professor of Department of Preschool and Social Pedagogy, Center for Higher School Methodology. Doctor of pedagogical Sciences. ORCID: https://orcid.org/0000-0001-8163-8273. E-mail: svetfed65@rambler.ru

${ }^{4}$ Moscow State Regional University (MGOU), Moscow - Russia. Professor of the Department of Labor Psychology and Organizational Psychology. Doctor of psychology. ORCID: https://orcid.org/0000-0001-51460064. E-mail: giv414@gmaik.com

${ }^{5}$ Kazan Federal University (KPFU), Kazan - Russia. Professor of the Department of Learning and Education Methodology, Institute of Psychology and Education. E-mail: gdautova@mail.ru
} 
well as to carry out comparative studies for improvement of education quality of future teachers.

KEYWORDS: Occupational standard. Education in the field of psychology and pedagogy. Federal state educational standard. Digitalization of education. Ethnocultural competency. Electronic educational environment.

RESUMO: A atualidade deste problema de pesquisa está baseada na necessidade de criar um ambiente educacional digital e expandir as perspectivas de educação online, realizada em correspondência com o projeto "Ambiente educacional digital moderno", aprovado pelo Governo da Federação Russa no âmbito da implementação do programa estatal "Desenvolvimento da educação" em 2013-2020. No contexto da digitalização da educação, os requisitos para as competências etnoculturais dos professores também mudam e adquirem novos conteúdos. Consequentemente, o objetivo da pesquisa é elaborar e analisar o conteúdo das competências etnoculturais no contexto da digitalização da educação, bem como revelar $e$ verificar experimentalmente a eficácia da experiência prática de uma instituição educacional na formação das futuras competências etnoculturais dos professores. Este artigo discute a experiência da Faculdade de Psicologia e Pedagogia, da Universidade Estadual de Mari, nesta direção. Métodos de pesquisa: métodos teóricos, no que diz respeito aos métodos empíricos, um questionário e uma experiência pedagógica foram utilizados. Os 50 participantes deste experimento são estudantes do quarto e quinto ano que buscam um bacharelado em Psicologia e Pedagogia. Os resultados da pesquisa concluem que é necessário implementar abordagens sistêmicas e civilizacionais ao formar competências etnoculturais de futuros professores no contexto da digitalização da educação. Neste caso, será possível formar uma pessoa adequada à economia digital e capaz de utilizar as tecnologias digitais em seu trabalho etnicamente orientado. Estes resultados de pesquisa podem ser aplicados para elaborar currículos e programas de cursos acadêmicos do ensino superior, assim como para realizar estudos comparativos para a melhoria da qualidade educacional dos futuros professores.

PALAVRAS-CHAVE: Padrão ocupacional. Educação no campo da psicologia e pedagogia. Padrão educacional do estado federal. Digitalização da educação. Competência etnocultural. Ambiente educacional eletrônico.

RESUMEN: La actualidad de este problema de investigación se basa en la necesidad de crear un entorno educativo digital y ampliar las perspectivas de la educación en línea que se realiza en correspondencia con el proyecto "Entorno educativo digital moderno", aprobado por el Gobierno de la Federación de Rusia en el marco de implementar el programa estatal "Desarrollo educativo" en 2013-2020. En el contexto de la digitalización de la educación, los requisitos de las competencias etnoculturales de los profesores también cambian y adquieren nuevos contenidos. En consecuencia, el objetivo de la investigación es elaborar y analizar el contenido de las competencias etnoculturales en el contexto de la digitalización de la educación, así como revelar y verificar experimentalmente la efectividad de la experiencia práctica de una institución educativa en la formación de las competencias etnoculturales de los futuros docentes. Este artículo analiza la experiencia de la Facultad de Psicología y Pedagogía de la Universidad Estatal de Mari en esta dirección. Métodos de investigación: métodos teóricos, en lo que se refiere a métodos empíricos, se utilizó un cuestionario y un experimento pedagógico. Los 50 participantes de este experimento son estudiantes de cuarto

RPGE- Revista on line de Política e Gestão Educacional, Araraquara, v. 25, n. esp. 1, p. 439-450, mar. 2021 e-ISSN:1519-9029 
y quinto año que cursan una licenciatura en Psicología y Pedagogía. Resultados y recomendaciones. Los resultados de esta investigación concluyen que es necesario implementar enfoques basados en sistemas y civilizaciones al formar las competencias etnoculturales de los futuros docentes en el contexto de la digitalización de la educación. En este caso, será posible formar una persona adecuada a la economía digital y capaz de utilizar las tecnologías digitales en su trabajo de orientación étnica. Estos resultados de investigación pueden aplicarse para diseñar planes de estudio y programas de cursos académicos de educación superior, así como para realizar estudios comparativos para mejorar la calidad de la educación de los futuros profesores.

PALABRAS CLAVE: Estándar profesional. Formación en el ámbito de la psicología y la pedagogía. Normativa educativa estatal federal. Digitalización de la educación. Competencia etnocultural. Entorno educativo electrónico.

\section{Introduction}

A distinctive feature of modern education development is its rapid transition to the internet sphere. At educational institutions of almost all levels (primary general, basic general, secondary general, secondary vocational, higher and supplementary education) the work with educational online-platforms has been started, a great number of online-courses are started, electronic services of education management are implemented, and digital technologies are used in learning.

Digitalization of education which implies an educational institution transition to electronic functioning is implemented in correspondence with the project "Modern digital educational environment", approved by the Government of the Russian Federation within the framework of implementing the state-run program "Education development" in 2013-2020. The passport of the priority project "Modern digital educational environment in the Russian Federation" approved in 2016 is an integral part of the Federal project "Vocational education competitiveness enhancement" which, in its turn, is a part of the National project "Education" and is planned for 2016-2021. The project is aimed at creating conditions for consistent quality and opportunity enhancement of ongoing education for all types of citizens through the development of the Russian digital educational environment and the increase in the number of students who complete online-courses at educational institutions ${ }^{6}$.

All this leads to the operational rearrangement of all subjects of the educational process and the rise in requirements for their competencies (FAKHRUTDINOVA; SHAMSUTDINOVA; RAMSIYA 2019; KHAIRUTDINOV et al., 2019). According to this

${ }^{6}$ Available: http://government.ru/projects/selection/643/25682/. Access: 10 dec. 2020.

RPGE- Revista on line de Política e Gestão Educacional, Araraquara, v. 25, n. esp. 1, p. 439-450, mar. $2021 . \quad$ e-ISSN:1519-9029 
standard, all teachers are supposed to have general user, general pedagogical and subject pedagogical (shows professional information and communication technology competence of a certain area of human activity) ICT competence ${ }^{7}$. Teachers with corresponding professional training and capable of using digital educational instruments are required (ANDREYEVA; FAKHRUTDINOVA; KORNEVA, 2019). The same requirement is given in the Federal state educational standards of higher education: "Functioning of electronic information educational environment is provided by corresponding information and communication technology means and staff qualification responsible for its usage and maintenance ${ }^{8}$.

In the context of education digitalization, the requirements for teachers' ethnocultural competencies also change and acquire new content.

On the whole, the term "ethnocultural competencies" is treated differently in the scientific literature. Several of the authors' approaches are given in Table 1.

Table 1 - Approaches to defining the term "ethnocultural competencies"

\begin{tabular}{|l|l|c|}
\hline Author & Definition & Resource \\
\hline Afanasieva, A. B. & $\begin{array}{l}\text { An integral personal quality which is exhibited as a complex of } \\
\text { knowledge about the culture of origin and ethnic cultures, their place } \\
\text { in the world culture as well as the experience of mastering } \\
\text { ethnocultural values and is displayed by a person in skills, abilities } \\
\text { and behavior models in monoethnic and polyethnic environment. }\end{array}$ & $\begin{array}{c}\text { Afanasieva } \\
(2009)\end{array}$ \\
\hline Morozov, I. A. & $\begin{array}{l}\text { Multiculturalism acknowledgment, possession of deep knowledge of } \\
\text { polyethnic entities and their culture, their difference understanding. }\end{array}$ & Morozov (2011) \\
\hline Poshtareva, T. V. & $\begin{array}{l}\text { A personality quality represented as the presence of a complex of } \\
\text { objective ideas and knowledge about ethnic culture and exhibited } \\
\text { through skills, abilities and behavior patterns that facilitate effective } \\
\text { interethnic mutual understanding and cooperation. }\end{array}$ & $\begin{array}{c}\text { Poshtareva } \\
(2009)\end{array}$ \\
\hline Popova, M. N. & $\begin{array}{l}\text { An integrative personality quality which is expressed as a complex of } \\
\text { knowledge and notions about the native and non-native ethnocultures } \\
\text { as well as skills and abilities essential for solving practical tasks of } \\
\text { preserving the ethnic, national and civil identity and preserving } \\
\text { interethnic peace and reconciliation in a multicultural society. }\end{array}$ & Popova (2019) \\
\hline
\end{tabular}

Source: Developed by the authors

The conducted teacher survey showed that the teachers commonly define ethnic and cultural competencies as "a personality quality which is expressed as the presence of a complex of objective ideas and knowledge about an ethnic culture", "notions of an ethnic culture", "a capability to adapt and effectively work in various cultures", "an ability to interact with representatives of various ethnocultures which is based on the knowledge of

${ }^{7}$ Available: https://base.garant.ru/70535556/. Access: 10 dec. 2020.

${ }^{8}$ Available: http://fgosvo.ru/uploadfiles/fgosvob/440302.pdf. Access: 10 dec. 2020.

RPGE- Revista on line de Política e Gestão Educacional, Araraquara, v. 25, n. esp. 1, p. 439-450, mar. $2021 . \quad$ e-ISSN:1519-9029 
their peculiarities, traditions, rules of conduct, acceptable in these cultures (AFANASIEVA, 2009; MOROZOV, 2011; POSHTAREVA, 2009; POPOVA, 2019).

\section{Methods}

\section{Research methods}

In this research theoretical methods among which analysis of the research subject based on studying cultural, psychological, and pedagogical literature as well as reflectivesystematic analysis of pedagogical work organization were used. As far as empirical methods are concerned, a questionnaire and a pedagogical experiment were used.

\section{Research experimental base}

This research experimental base was Federal State Budget Educational Institution of Higher Education "Mari State University". The 50 participants of this experiment are fourthand fifth-year full-time and extra-mural students pursuing a bachelor's degree in Psychology and Pedagogy.

\section{Research stages}

To reveal to what extent modern teachers and future teachers are informed about the subject matter of education digitalization and how they evaluate their competence in a digital educational environment the questionnaire was completed. This questionnaire included the following questions:

1. What is digitalization of education?

2. What are the pluses of digitalization?

3. Are there any minuses in digitalization of education?

4. How do you evaluate your competence in a digital educational environment?

5. How can digitalization of education influence teachers' digital competence formation?

\section{Results and discussion}

Giving answers to the first question, the teachers responded that digitalization of education is "a transition to a digital communication method, data recording and transmission 
by means of digital devices", "provision of wide access to information and digital resources and usage of digital technologies, available to everyone and displayed on modern digital devices", "a transition to an electronic learning environment", "a means for getting flexibility of an educational process, that provides a perfect result for learners and highly-proficient mobile specialists to employers", "creation of electronic schools, transition to distant learning", "video tutorials and an electronic record book", "usage of digital technologies in an educational process, teaching children with smart boards, laptops, broadband, and wi-fi", "introduction of the novelty in the system of education by means of high-tech solutions", "modern school education which is implemented by means of modern technology (a smart board, laptops, broadband internet)", "transition of educational institutions to a digital education which means that a conventional textbook is replaced by an electronic textbook while conventional lessons with a teacher and blackboard are replaced by a smart board".

Among the pluses of education digitalization the teachers mentioned that "it broadens possibilities for home-schooled students and gives rise to new educational technologies", "its main advantages are simplicity and correctness of receiving services, minimization of the human factor, avoidance of paper documents due to data storage in an electronic format", "a fast way of information transmission, storage of large quantities of information, conducting online webinars and lectures", "one can easily find necessary information on the internet, use of visual aids, independence of education", "information technologies will relieve teachers and give them more time for dealing with students", "any information can be found in a device, which is in a student's pocket", "availability, a possibility for extra mural studies, any time, absence of paper routine with homework", "time saving, cheap, distant", "studying any time, continuous learning, an opportunity to design individual learning routes, to turn from users of electronic resources into their designers, facilitation of teachers' work", "will help students to find their way in the world of information in the future", "will be of use to the younger generation, as now everything is connected with the internet", "no need to carry piles of books", "using electronic resources is sustainable as it contributes to ecology problem solution (deforestation, paper consumption)", "children with disabilities will have the same access to all the resources as other children", "students can themselves manage their time because they can access a course any time and listen to a lecture."

Some respondents gave rather detailed answers to this question:

1. All students can find more information in basic subjects such as Russian, Literature, History, Algebra, Geometry, Physics, Chemistry, and Biology. 
2. Video tutorials and an electronic record book are convenient for parents. Play-based learning, replacing a teacher by a virtual tutor and other options are available.

3. An electronic library is continuously supplemented with new editions. This process is particularly dynamic when preparing for accreditation and academic program certification according to new and updated Federal state educational standards.

4. Study materials, lesson plans, classes, registers and record books will be electronic. Students will be able to have classes via the internet without leaving home. There will be electronic resources where students will find detailed information for classes.

5. Digitalization implies self-studying.

6. With digital education you can do without piles of books and papers. A computer will fit all textbooks and study materials, a tablet will replace exercise-books.

7. Since with digitalization you can do without paper versions, parents will not have to spend money on exercise-books, textbooks, pens and other stationery.

8. Transition to a digital education is a significant stage in creating Internet technologies. Science is currently developing at a rapid rate, new structures appear daily. Digitalization of education will help students to find their way in the world of information in the future.

There were some teachers who did not manage to give pluses of digitalization.

Digitalization like any other process has its minuses. Among them the respondents mentioned that "educational institutions lack educational technologies and equipment, technologies are insufficiently developed", "it is necessary to purchase expensive equipment and to be able to use it", "there is no physical activity", "many people will be unemployed and teachers are among them", "the technologies are not tested, writing and creativity skills are lost, screen dependence", "social skills and intelligence decline", "electromagnetic emanation, health and eyesight decline", "computer dependence, information from the screen is perceived inadequately", "there exists an electronic folder and a family is observed", "bad socialization", "people will be replaced by robots and virtual systems, as a result people will lose jobs", "a serious gadget dependence will appear", "one can get involved in a cybercrime", "when studying a video tutorial, you have no opportunity to ask questions", "internet addiction will develop", "if schools become digital, children will not have to go to school and will lose a chance to find new friends. For many students communication is essential but with digitalization they will not have this experience. To get access to onlinecourses and lectures the internet is necessary. The internet and the broadband internet are not 
available for everyone. One does not need money to get to an educational institution unless one has to use public transport", "a risk of getting in digital slavery is worrisome", "there can develop dependence on technical devices which are likely to break or fail". There were some respondents who were uncertain about the minuses as well as there were some who denied minuses of digitalization.

Evaluating their own competence in digital education environment, teachers gave the following responses: "I evaluate my competence as average", "competence of an average level", "in general quite positively", "it would do good to take qualification upgrading courses", "I evaluate my competence in digital education environment as insufficient", "my competence is of an average level. As there is always room for perfection I study and use ICT in my life because they make it easier". There were some positive responses: "I evaluate my level as higher than average but I might not know details"; "I think I know internet resources quite well and easily find my way in a digital education environment", "I evaluate my digital education environment competence as good. I am able to use a major part of the above mentioned resources, but electronic resources are updated annually, so there is always room for self-education"; "My knowledge and skills of ICT are quite sufficient. In digital environment it is essential to be able to specify and organize the information of interest as there is more than necessary in the sphere of information technologies. A digital environment gives me great possibilities for teaching children, I can find information that will be useful for me and interesting for children"; "I think I am quite competent in a digital education. At our university there is an electronic course where we complete tasks in many subjects"; "I evaluate my digital education environment competence as quite high". Some respondents could not evaluate their competence in a digital education environment responding.

The answers to the question about the way digitalization of education can influence teachers' digital competence formation were as follows: "There will be possibilities for conducting lessons, lectures and seminars at a new level"; "teachers will spend less time on administrative work (monitoring, reports, written work assessment), multimedia makes a class more interesting"; "every teacher will be influenced differently either positively or negatively"; "a modern teacher should be aware of everything, find his way in a digital environment of the internet, should be able to search for new knowledge, various types data, required facts and information as well as ways of dealing with them"; "a modern teacher should have general digital skills (online searching, office software usage), complementary digital skills for accomplishing new tasks (using social networks and other digital messengers for communicating with students and parents), and special skills of using the latest services of 
digital economy (cloud technologies and storages for placing educational content)"; "there will be a different type of teacher's mentality, different modes of work with students, a teacher will be a guide in the digital world"; "a learning process will be adapted to educational demands and interests of every student"; "with digitalization of education it will be easier for a teacher with ICT competence to adapt to a new system of education, to get new knowledge in this field while new qualification upgrading courses for teachers will be highly demanded"; "when digitalization is introduced into education, teachers' digital competence formation grows irrespective of teachers"; "digitalization of education is continuously developing, it cannot but influence teachers"; "Teachers are faced with the fact that they are to deal with digital technologies. At present all classes involve technology, reports and documents are fulfilled and processed electronically. Anyway, teachers will have to face the need for their digital competence formation with digitalization giving them great possibilities"; "digital skills enable teachers to create and exchange digital content, to communicate and find solutions at work and in social life"; "young teachers are likely to favor such an approach to learning". There were some respondents who did not manage to answer this question.

\section{Discussion}

As we have already stated, digitalization of education sets new requirements to teachers' ethnocultural competences that acquire new content when a teacher accomplishes professional tasks in a digital educational environment.

First thing, it should be pointed out that many authors treat the terms "ethnocultural competence" and "ethnocultural proficiency" as synonymous. We do not support this opinion and differentiate between them. By ethnocultural proficiency we understand a systematic integral person's structure in the unity of its static and dynamic characteristics which reflects an individual's ability to successfully adapt and realize the potential in an ethnocultural environment. As the structural components of ethnocultural proficiency we considered ethnopedagogical, ethno-psychological and multicultural aspects that belong to proficiency characteristics (FEDOROVA, 2002, p. 98). Ethnocultural proficiency is in use characterized by a complex of ethnocultural competences (CHUMAROVA; VINNIKOVA; FAKHRUTDINOVA, 2019). The respondents to the survey have admitted that they do not possess ethnocultural competences to the full extent. Digitalization of education will enable them to master them: 
- electronic training programs will enable them to master ethnocultural norms and basics of moral conduct;

- $\quad$ education platforms will help them to develop the ability to consistently and correctly formulate ideas in a native literary language;

- online-courses will contribute to improving oral and written speech skills, public speaking skills, and scientific text processing;

- $\quad$ software product usage will help them to master basic methods, ways, and means of getting, storing and crunching ethnocultural knowledge;

- digital educational recourses will enable them to realize the meaning and importance of information in the multicultural society development;

- digital tools will serve as the basis, developing the capability to work with information in global computer networks;

- $\quad$ taking online-training will enable them to develop the capability to take into account ethnocultural and confessional differences of educational process participants in the course of social interaction (FAHRUTDINOVA; SOLOVYOVA, 2014; FEDOROVA, 2017; TERENTYEVA; STARODUBTSEV; TIMONIN, 2016).

\section{Conclusions}

This research makes it possible to come to the conclusion that it is necessary to implement system-based and civilizational approaches when forming ethnocultural competences of future teachers in the context of education digitalization. In this case, it will be possible to form a person adequate to the digital economy and able to use digital technologies in their ethnically oriented work.

ACKNOWLEDGEMENTS: The work is performed according to the Russian Government Program of Competitive Growth of Kazan Federal University.

\section{REFERENCES}

AFANASIEVA, A. B. Ethno-cultural education: subject-matter, structure, contents and problems of improvement. Proceedings of Russian State Pedagogical University, p. 189195, 2009. 
ANDREYEVA, Y. A.; FAKHRUTDINOVA, A. V.; KORNEVA, I. G. The effectiveness of the use of computer technology compared to the traditional methods in the process of a foreign language teaching. Universal Journal of Educational Research, v. 7, n. 10 B, p. 21$26,2019$.

CHUMAROVA, L. G; VINNIKOVA, M. N; FAKHRUTDINOVA, A. V. Theological and educational ideas of the Tatar enlightener Kayum Nasyri. Humanities and Social Sciences Reviews, v. 7, n. 6, p. 89-92, 2019.

FAHRUTDINOVA, G. Z.; SOLOVYOVA, E. G. Formation of the value-oriented polycultural personality of a future teacher in the contemporary education space. Life Science Journal, v. 11, n. 11, p. 272-276, 2014.

FAKHRUTDINOVA, A. V.; SHAMSUTDINOVA, D. V.; RAMSIYA, N. G. Paradigmatic methodology of civic culture formation process in young generation. Journal of Sociology and Social Anthropology, v. 10, n. 4, p. 198-202, 2019.

FEDOROVA, S. N. Modern teachers' ethno-cultural competences: subject matter and content characteristics. In: ALL-RUSSIA RESEARCH-TO-PRACTICE CONFERENCE, 13., 2017, Yoshkar-Ola. Proceedings [...]. Yoshkar-Ola: GBY DPO, 2017.

FEDOROVA, S. N. Teacher's ethno-cultural proficiency. Yoshkar-Ola: MarGPI, 2002.

KHAIRUTDINOV, R. R. et al. The content of educational programs in technical universities: Quality of applying the modern professional standards. International Journal of Instruction, v. 12, n. 1, p. 357-360, 2019.

MOROZOV, A. I. Ethno-cultural proficiency and second generation general education standards. Proceedings of International Scientific Conference, p. 49-52, 2011.

POPOVA, M. N. Forming senior high school students' ethno-cultural competence in the regional educational environment. Mir nauki, kyltyri, obrazovaniya - The world of science, culture and education, v. 1, n. 74, p. 142-144, 2019.

POSHTAREVA, T. V. Forming students' ethno-cultural proficiency in polyethnic educational environment. Vladikavkas, 2009.

RUSSIA. Order of the Ministry of Labor and Social Protection of the Russian Federation $\mathrm{n}$. 544H "On the approval of the Occupational standard "Teacher (pedagogical work in preschool, primary general, basic general, secondary general education) (nursery teacher, teacher)". oct. 2013. Available: https://base.garant.ru/70535556/. Access: 10 dec. 2020.

RUSSIA. Order on the approval of Federal state educational standard of higher education, field of education 44.03.02 Psychological and pedagogical education (baccalaureate). jan. 2016. Available: http://fgosvo.ru/uploadfiles/fgosvob/440302.pdf. Access: 10 dec. 2020.

RUSSIA. Passport of the priority project Modern digital educational environment in the Russian Federation. 2016. Available: http://government.ru/projects/selection/643/25682/. Access: 10 dec. 2020. 
TERENTYEVA, I. V.; STARODUBTSEV, M. P.; TIMONIN, A. I. Assessment of state services quality and availability in the socio-cultural sphere. International Review of Management and Marketing, v. 6, n. 1, p. 122-127, 2016.

\section{How to reference this article}

TERENTYEVA, I. V.; FAKHRUTDINOVA, A. V.; FEDOROVA, S. N.; GAIDAMASHKO, I. V.; FAHRUTDINOVA, G. Z. Ethnocultural competencies of a teacher in the context of education digitalization. Revista on line de Política e Gestão Educacional, Araraquara, v. 25, n. esp. 1, p. 439-450, mar. 2021. e-ISSN:1519-9029. DOI: https://doi.org/10.22633/rpge.v25iesp.1.14981

Submitted: 06/11/2020

Required revisions: 18/01/2021

Approved: $23 / 02 / 221$

Published: 01/03/2021 